tion for Economic Co-operation and Development, Paris, 2003).

19. U.S. Department of Agriculture, Office of the Chief Economist, USDA Agricultural Baseline Projections to 2012 (Staff Report WAOB-2003-1, U.S. Department of Agriculture, Washington, DC, 2003).

20. M. W. Rosegrant, S. Meijer, S. A. Cline, "International Model for Policy Analysis of Agricultural Commodities and Trade (IMPACT): Model description" (IFPRI, Washington, DC, 2002), available at www.ifpri.org/themes/impact/impactmodel.pdf.

21. International Food Policy Research Institute, unpublished data.

22. World Bank, Poverty: World Development Indicators (Oxford Univ. Press, New York, 1990).

23. World Bank, Poverty Reduction and the World Bank: Progress and Challenges in the 1990s (The International Bank for Reconstruction and Development/The World Bank, Washington, DC, 1996).

24. A. Kassouf, B. Senauer, Econ. Dev. Cult. Change 44 817 (1996).

25. M. Lipton, S. Yaqub, E. Darbellay, Success in AntiPoverty (International Labour Office, Geneva, 1998).

26. R. Gaiha, Design of Poverty Alleviation Strategy in Rural Areas (FAO, Rome, 1994).

27. R. Singh, P. Hazell, Econ. Polit. Wkly. 28, A9 (20 March 1993).

28. A. Croppenstedt, C. Muller, Econ. Dev. Cult. Change 48, 475 (2000).
29. International Fund for Agricultural Development (IFAD), The State of World Rural Poverty: A Profile of Asia (IFAD, Rome, 1995).

30. S. Fan, P. Hazell, S. Thorat, Am. J. Agric. Econ. 82 , 1038 (2000).

31. S. Fan, L. Zhang, X. Zhang, "Growth, inequality, and poverty in rural China: The role of public investments" (IFPRI Research Report 125, IFPRI, Washington, DC, 2002)

32. J. M. Alston, P. G. Pardey, C. Chan-Kang, T. J. Wyatt, M. C. Marra, "A meta-analysis of rates of return to agricultural R\&D: Ex pede Herculem?" (IFPRI Research Report 113, IFPRI, Washington, DC 2000).

33. The harvest index is defined as "the ratio of grain to total crop biomass" (34).

34. K. G. Cassman, Proc. Natl. Acad. Sci. U.S.A. 96, 5952 (1999).

35. L. T. Evans, Feeding the Ten Billion: Plants and Population Growth (Cambridge Univ. Press, Cambridge, 1998)

36. West Africa Rice Development Association, "Consortium formed to rapidly disseminate New Rice for Africa," available at www.warda.org/warda1/ main/newsrelease/newsrel-consortiumapr01.htm [cited 2000]

37. D. Byerlee, K. Fischer, "Accessing modern science: Policy and institutional options for agricultural biotechnology in developing countries" (Agricultural
Knowledge and Information Systems Discussion Paper, The World Bank, Washington, DC, 2000).

38. M. W. Rosegrant, X. Cai, S. A. Cline, World Water and Food to 2025: Dealing with Scarcity (IFPRI, Washington, DC, 2002).

39. S. M. Barghouti, Sustain. Dev. Int. 1, 127 (2001), www.sustdev.org/agriculture/articles/edition $1 / 01$. 127.pdf.

40. Food and Agriculture Organization of the United Nations, Crops and Drops (FAO, Rome, 2000).

41. J. Pretty, Environ. Dev. Sustain. 1, 253 (1999)

42. J. Pretty, World Dev. 23, 1247 (1995).

43. T. Oweis, A. Hachum, J. Kijne, "Water harvesting and supplementary irrigation for improved water use efficiency in dry areas" (System-Wide Initiative on Water Management Paper 7, International Water Management Institute, Colombo, Sri Lanka, 1999).

44. S. Ceccarelli, S. Grando, R. H. Booth, in Participatory Plant Breeding, P. Eyzaguire, M. Iwanaga, Eds. (International Plant Genetics Research Institute, Rome, 1996), pp. 99-116.

45. J. Kornegay, J. A. Beltran, J. Ashby, in Participatory Plant Breeding, P. Eyzaguire, M. Iwanaga, Eds. (International Plant Genetics Research Institute, Rome, 1996), pp. 151-159.

Web Resources

www.sciencemag.org/cgi/content/full/302/5652/1917/ DC1

VIE WPOINT

\title{
New Visions for Addressing Sustainability
}

\author{
A. J. McMichael, ${ }^{1 *}$ C. D. Butler, ${ }^{1}$ Carl Folke ${ }^{2}$
}

\begin{abstract}
Attaining sustainability will require concerted interactive efforts among disciplines, many of which have not yet recognized, and internalized, the relevance of environmental issues to their main intellectual discourse. The inability of key scientific disciplines to engage interactively is an obstacle to the actual attainment of sustainability. For example, in the list of Millennium Development Goals from the United Nations World Summit on Sustainable Development, Johannesburg, 2002, the seventh of the eight goals, to "ensure environmental sustainability," is presented separately from the parallel goals of reducing fertility and poverty, improving gains in equity, improving material conditions, and enhancing population health. A more integrated and consilient approach to sustainability is urgently needed.
\end{abstract}

For human populations, sustainability means transforming our ways of living to maximize the chances that environmental and social conditions will indefinitely support human security, wellbeing, and health. In particular, the flow of nonsubstitutable goods and services from ecosystems must be sustained. The contemporary stimulus for exploring sustainability is the accruing evidence that humankind is jeopardizing its own longer term interests by living beyond Earth's means, thereby changing atmospheric composition and depleting biodiversity, soil fertility, ocean fisheries, and freshwater supplies (1).

Much early discussion about sustainability has focused on readily measurable intermediate outcomes such as increased economic perfor-

${ }^{1}$ National Centre for Epidemiology and Population Health, Australian National University, Canberra, ACT 0200, Australia. 2Department of Systems Ecology, Stockholm University, Stockholm, Sweden.

*To whom correspondence should be addressed. Email: tony.mcmichael@anu.edu.au mance, greater energy efficiency, better urban design, improved transport systems, better conservation of recreational amenities, and so on. However, such changes in technologies, behaviors, amenities, and equity are only the means to attaining desired human experiential outcomes, including autonomy, opportunity, security, and health. These are the true ends of sustainability - and there has been some recognition that their attainment, and their sharing, will be optimized by reducing the rich-poor divide (2).

Some reasons for the failure to achieve a collective vision of how to attain sustainability lie in the limitations of, and disjunction between, disciplines we think should be central to our understanding of sustainability: demography, economics, ecology, and epidemiology. These disciplines bear on the size and economic activities of the human population, how the population relates to the natural world, and the health consequences of ecologically injudicious behavior. Sustainability issues are of course not limited to these four disciplines, but require the engagement and inter- disciplinary collaboration of other social and natural sciences, engineering, and the humanities (3).

Neither mainstream demography nor economics, for the most part, incorporates sufficient appreciation of environmental criticalities into their thinking. They implictly assume that the world is an open, steady-state system within which discipline-specific processes can be studied. Although contemporary ecology has broadened its perspectives significantly, there is a tendency to exclude consideration of both human influence and dependence on ecosystem composition, development, and dynamics. Epidemiologists focus mainly on individual-level behaviors and circumstances as causes of disease. This discounts the underlying social, cultural, and political determinants of the distribution of disease risk within and between populations, and has barely recognized the health risks posed by today's global environmental changes.

These four disciplines share a limited ability to appreciate that the fate of human populations depends on the biosphere's capacity to provide a continued flow of goods and services. The assumption of human separateness from the natural world perpetuates a long-standing, biblically based premise of Western scientific thought of Man as master, with dominion over Nature (4). Many disciplines still apply world views that predate current understanding of complex system dynamics and of how human evolutionary history has developed with, and helped shape, 
natural phenomena $(5,6)$. Their intellectual legacies need to be updated and integrated within an organized scientific effort spanning a range of disciplines that are currently not in effective communication. This would provide essential input to the sustainability discourse.

\section{Resource Imbalances}

Little demographic literature addresses the role of resource imbalances as a putative root cause for some of the changes observed in fertility and regional life expectancies $(7,8)$. The notion of human carrying capacity (9) is generally dismissed as irrelevant (10-12), as if humans, uniquely among species, have transcended environmental dependency. It is true that humans, through cultural developments such as agriculture, trade, and fossil-fuel combustion, have increased the carrying capacity of local environments, at least in the short to medium term. We may yet raise those limits further, or we may now be seeing early evidence of having recently exceeded the global carrying capacity, new technologies notwithstanding. We do not yet know which. Meanwhile, demographers display little awareness of the likely impacts of global environmental changes on future changes in human population size (13). The recent decline in global population growth rate has been generally welcomed by demographers (though noting the attendant problems of population aging and increased dependency ratios), suggesting that, for some, the issue of sustainability is recognized. The world view of many demographers still inclines toward that of many economists in assuming a setting free of the constraints of the carrying capacity of the biosphere.

\section{Market Choices}

The role of market forces is central to modern economics, and the turnover of goods and services is considered an indicator of progress. Instead of recognizing that the human economy is a dependent subset of the biosphere, many economists still assume that economic growth and liberalization, with wealth creation, is the key to affording adequate environmental management. Environmental quality is believed to be most effectively achieved through market forces, even as social and environmental costs are "externalized." This view also assumes that environmental change is generally incremental, thereby overlooking the time-lagged, threshold, and irreversible effects that characterize many human and ecological systems.

The growing interdisciplinary domain of environmental and ecological economics appreciates the significance of the Earth system's functioning for human well-being, and, therefore, the need to sustain its capacity to support economic development $(14,15)$. The economics of complex system dynamics and its implications for sustainability have also been addressed (16). Indeed, ecological economics treats environmental sustainability and human carrying capacity as central premises for economic development (17).

\section{Ecosystems and Human Society}

Ecologists understand the structure, functioning, and interdependencies of populations and ecosystems and, increasingly, appreciate the interplay of the natural world with human systems. However, various conceptual and theoretical frameworks in ecology still disregard the connection to the human species. More integrated views from landscape ecology and systems approaches, and the greater appreciation of complex systems, critical thresholds, and the possibilities of state changes, are attracting attention $(18,19)$.

Over the past decade, the fledgling field of "ecosystem health" has been fostered in interdisciplinary fashion $(20,21)$. There is increasing recognition that humans are themselves a major force in ecosystem development and evolution. Integrative approaches to coevolving socialecological systems have emerged $(22,23)$. The ongoing Millennium Ecosystem Assessment Project, funded by several international environmental-biological conventions and other international agencies, has brought together many scientists to address interdisciplinary questions relating to the current and future conditions of the world's ecosystems and the consequences for human societies (24).

\section{Risk of Disease}

During the recent development of epidemiology as a modern discipline, populations have been increasingly viewed as aggregations of individuals exercising free choices. Accordingly, contemporary epidemiology has focused on quantifyingthecontributionofspecificindividuallevel factors to disease risk. However, the resurgence of infectious disease, including particularly HIV/AIDS and various other newly identified infections, has underscored the importance of population-level phenomena, including social conditions, cultural practices, and technological choices. Similarly, dramatic changes in health and life expectancy in the countries of central and eastern Europe and the former Soviet bloc, following the collapse of communism, highlight the fundamental importance of social, economic, and political conditions to population health $(25,26)$. Meanwhile, there is nascent recognition that climate change and other global environmental changes pose risks to human health, both now and, more so, in the future (27).

\section{Responding to the Crisis}

Addressing sustainability is more than an academic exercise. It is a vital response to a rapidly evolving crisis and should be at the top of our research agendas. The forces that oppose social change for sustainability, whether from indifference, incomprehension, or self-interest, are powerful, and neither individual scientists nor isolated scientific disciplines will suffice to change understanding and policy. Science itself needs to be fully engaged in this challenge (28). The "science of human-environment interactions" (29) and "sustainability science" have emerged over the past decade (30). A combination of inter- and transdisciplinary approaches to sustainability, unconstrained by traditional disciplinary domains and concepts, must be encouraged.

Such approaches may prove difficult to achieve within conventional university departments, and purpose-built interdisciplinary centers will therefore be needed. Other support will come from interdisciplinary societies (e.g., International Association for the Study of Common Property), research institutes (e.g., Santa Fe Institute; Beijer Institute, Stockholm; National Center for Ecological Analysis and Synthesis, Santa Barbara; International Institute for Applied Systems Analysis, Vienna), and research networks [e.g., Sustainability Science network on vulnerability, Resilience Alliance, International Council for Science (ICSU) initiative on sustainability, International Geosphere Biosphere Program, and International Human Dimensions Program on Global Environmental Change]. Achieving a sufficiently intensive interdisciplinary collaboration, on a large enough canvas to meet the needs of sustainability, remains the central challenge.

\section{References}

1. P. H. Raven, Science 297, 954 (2002).

2. C. D. Butler, Global Change Hum. Health 1, 156 (2000).

3. E. Ostrom et al., The Drama of the Commons (National Academy Press, Washington, DC, 2002).

4. L. White, Science 155, 1203 (1967).

5. C. L. Redman, Human Impact on Ancient Environments (Univ. of Arizona Press, Tucson, AZ, 1999).

6. R. J. McIntosh et al., The Way the Wind Blows (Columbia Univ. Press, New York, 2000).

7. R. A. Easterlin, Am. Econ. Rev. 61, 399 (1971).

8. V. D. Abernethy, Population Politics: The Choices That Shape Our Future (Plenum, New York, 1993).

9. G. Daily, P. R. Ehrlich, BioScience 42, 761 (1992).

10. C. André, J. P. Platteau, J. Econ. Behav. Org. 34, 1 (1998).

11. C. D. Butler, Ecosyst. Health 6, 171 (2000).

12. J. E. Cohen, Science 269, 341 (1995).

13. P. Demeny, Popul. Dev. Rev. 14, 213 (1988).

14. K. Arrow et al., Science 268, 520 (1995).

15. K. G. Mäler, Eur. Econ. Rev. 44, 645 (2000).

16. W. B. Arthur, Science 284, 107 (1999).

17. R. Costanza et al., The Development of Ecological Economics (Elgar, London, 1997).

18. S. A. Levin, Fragile Dominion: Complexity and the Commons (Perseus Books, Reading, MA, 1999).

19. M. Scheffer et al., Nature 413, 591 (2001).

20. D. Rapport, R. Costanza, A. J. McMichael, Trends Ecol. Evol. 13, 397 (1998).

21. A. Aguirre et al., Conservation Medicine: Ecological Health in Practice (Oxford Univ. Press, New York, 2002).

22. L. H. Gunderson, C. S. Holling, Panarchy: Understanding Transformations in Human and Natural Systems (Island, Washington, DC, 2002).

23. F. Berkes et al., Navigating Social-Ecological Systems: Building Resilience for Complexity and Change (Cambridge Univ. Press, Cambridge, 2003).

24. Millennium Assessment Web site: www. millenniumassessment.org.

25. A. J. McMichael, Am. J. Epidemiol. 149, 887 (1999).

26. L. Berkman, I. Kawachi, Social Epidemiology (Oxford Univ. Press, Oxford, 2001).

27. A. J. McMichael, R. Beaglehole, Lancet 356, 495 (2000).

28. J. Lubchenco, Science 279, 491 (1998).

29. P. C. Stern, Science 260, 1897 (1993).

30. National Research Council, Our Common Journey: $A$ Transition Toward Sustainability (National Academy Press, Washington, DC, 1999).

Web Resources

www.sciencemag.org/cgi/content/full/302/5652/1919/DC1 